\title{
Revival of Isolated Hearts Stopped with Alcohol and Glucocorticoids by Nicotine and Acetylcholine
}

\author{
G.L. PathaK, M.B.B.S., M.D., Ph.D.
}

\section{SUMMARY}

Investigations on the influence of nicotine and acetylcholine on isolated 30 frog and 10 rabbit hearts stopped with $0.5 \mathrm{ml}$ of $50 \%$ alcohol and 0.1 to $0.5 \mathrm{ml}$ of 0.5 to $1 \%$ cortisone, hydrocortisone and prednisolone indicated that 0.1 to $3 \mathrm{ml}$ of $10^{-4} \mathrm{Gm} / \mathrm{ml}$ of nicotine restarted the stopped hearts. Acetylcholine in a dose of 0.1 to $3 \mathrm{ml}$ of $10^{-7}$ to $10^{-4} \mathrm{Gm} / \mathrm{ml}$ was less effective in restarting the stopped hearts. Prior or simultaneous administration of nicotine or acetylcholine prevented occurrence of cardiac asystole with alcohol and glucocorticoids or cut short its duration. Prior administration of alcohol modified the action of nicotine. Catecholamine release from cardiac neural elements does not appear to be involved in antiasystolic action of nicotine and acetylcholine. It has been suggested that asystolic and antiasystolic actions may be coupled with a common receptor or enzyme system through which drugs produce biphasic and opposite effects depending upon concentration.

\section{Additional Indexing Words:}

Revival of heart Cardiac asystole Glucocorticoids Alcohol Cortisone Hydrocortisone Prednisolone Nicotine Acetylcholine Isolated hearts

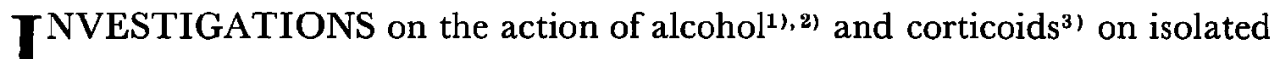
amphibian and mammalian hearts showed that high doses of these substances produced reversible transient cardiac asystole. Earlier experiments on revival of hearts had shown that spontaneously stopped hearts could be revived with acetylcholine and nicotine. ${ }^{4)}$ It was pertinent to see if acetylcholine and nicotine had any reviving effect on hearts stopped with alcohol and corticoids. The results of these investigations are considered in this paper.
\end{abstract}

\section{Material and Methods}

The isolated frog hearts were perfused with oxygenated frog's Ringer solution ( $\mathrm{NaCl}, 102 \mathrm{mM} ; \mathrm{KCl}, 1 \mathrm{mM}$; $\mathrm{CaCl}_{2}, 1 \mathrm{mM} ; \mathrm{NaHCO}_{3}, 1 \mathrm{mM}$; glucose, $5 \mathrm{mM}$; pH 7.6) by introducing a Syme's cannula into the posterior vena cava. An auto-

From the Department of Physiology, Biophysics and Biochemistry, Medical College, Jodhpur (Rajasthan), India.

Received for publication March 15, 1973. 
matic overflow device was used to avoid fluctuations in the amplitude and frequency of heart beat as a result of changes in the perfusion pressure. ${ }^{5}$ Isolated rabbit hearts were perfused with oxygenated Ringer-Locke solution $(\mathrm{NaCl}, 155 \mathrm{mM}$; $\mathrm{KCl}, 5.6 \mathrm{mM}$; $\mathrm{CaCl}_{2}, 2 \mathrm{mM}$; $\mathrm{NaHCO}_{3}, 2.5 \mathrm{mM}$; glucose, $5 \mathrm{mM}$; $\mathrm{pH} 7.6$ ) through coronary vessels. The record of heart beat was taken on a slowly moving smoked kymograph paper.

Test solutions of corticoids were prepared by dissolving $100 \mathrm{mg}$ of solid cortisone acetate, hydrocortisone acetate or prednisolone in small volume of $50 \%$ alcohol in Ringer. These solutions were diluted with Ringer to get the desired strengths. Previous work has shown that 0.1 to $0.3 \mathrm{ml}$ of $0.5 \%$ solution of cortisone, hydrocortisone and prednisolone and $0.5 \mathrm{ml}$ of $50 \%$ alcohol stopped the heart. Although the small amount of alcohol present in the corticoid test solution was not enough to cause cardiac asystole, it was considered desirable to run regular control tests with corresponding strengths of alcohol.

The test solutions were administered by adding them to the $2.5 \mathrm{ml}$ of Ringer fluid present in the Syme's cannula. Thus each test solution was diluted by a known factor in frog hearts. The final concentrations could be calculated from this dilution factor. In case of rabbit hearts the test solutions of corticoid at room temperature were administered by injecting into the perfusion tubing close to the heart with appropriate precautions to avoid changes in pressure and temperature. Alcohol controls were also conducted side by side. The test solution was considerably diluted in the perfusion fluid, hence asystole in rabbit hearts was shorter than in frog heart inspite of the fact that rabbit hearts were more sensitive. The dose was increased to produce a longer asystole if needed.

Experiments were conducted on 30 frog and 10 rabbit hearts. The hearts were stopped with appropriate dose of alcohol and corticoid and the effect of acetylcholine and nicotine on the duration of asystole was investigated.

\section{Results}

The results of experiments on the influence of acetylcholine and nicotine on the duration of cardiac asystole produced by alcohol and glucocorticoids in 30 frog and 10 rabbit hearts, are considered below.

\section{Alcohol:}

0.5 to $1 \mathrm{ml}$ of $50 \%$ alcohol was used for producing cardiac asystole both in frog and rabbit hearts. Nicotine 0.5 to $3 \mathrm{ml}$ of $10^{-4} \mathrm{Gm} / \mathrm{ml}$ was effective in restarting the hearts stopped by alcohol. Fig. 1 shows the record of a frog heart. Panel 1 shows that $0.5 \mathrm{ml}$ of $50 \%$ alcohol produced cardiac asystole for $6 \mathrm{~min}$. Administration of $1 \mathrm{ml}$ of $10^{-4} \mathrm{Gm} / \mathrm{ml}$ of nicotine caused slight acceleration with rise in the baseline (increased tone) and reduction in ventricular relaxation. The heart resumed normal activity very gradually. Subsequently the same dose of nicotine was administered $45 \mathrm{sec}$ after producing cardiac asystole by repeating the same dose of alcohol. The heart restarted with acceleration and slightly raised baseline showing miniature effect of nicotine. 

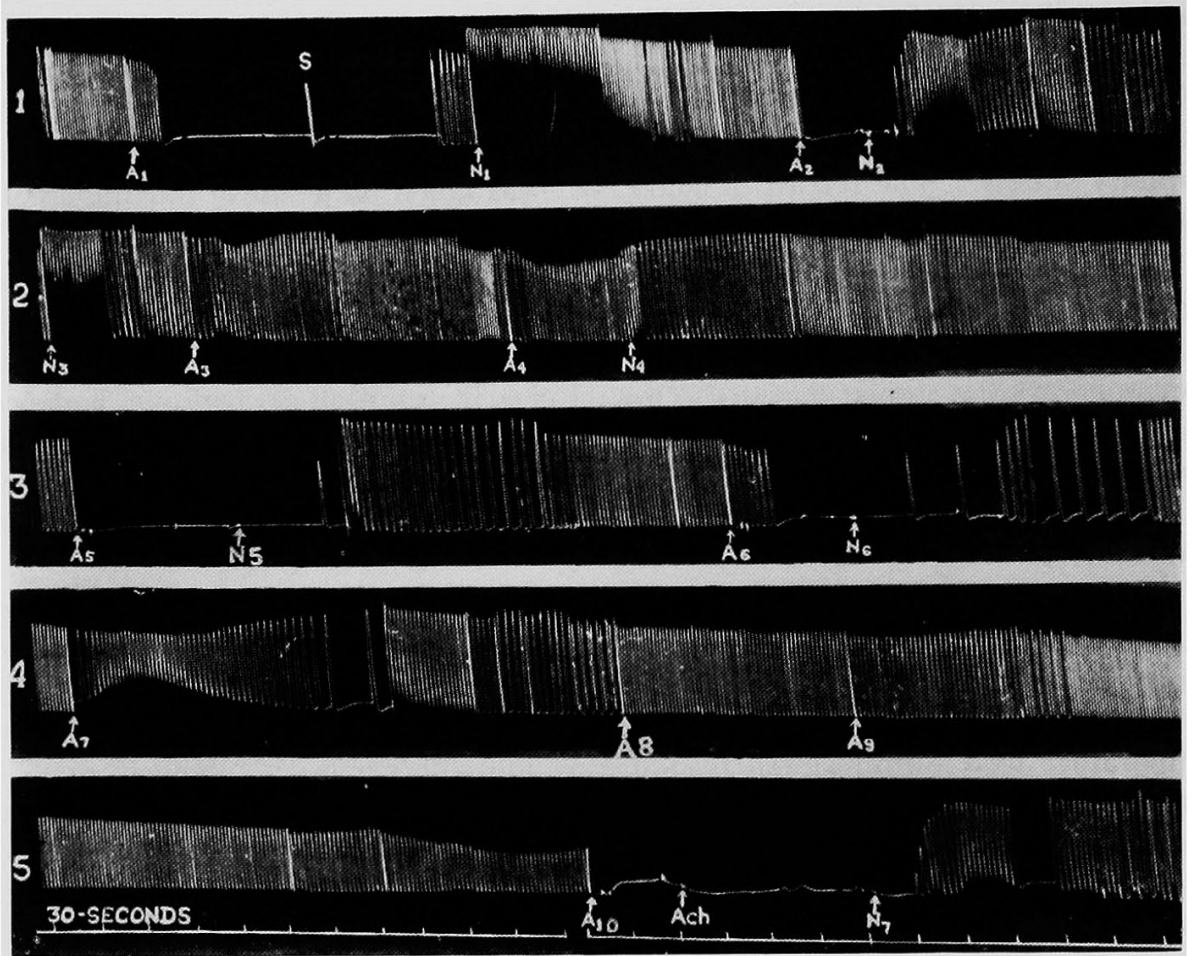

Fig. 1. Extracts of record of a frog heart. $\mathrm{S}$ and similar other bold white lines indicate stoppage of drum. Strength of alcohol 50\% in Ringer's solution; strength of nicotine $10^{-4} \mathrm{Gm} / \mathrm{ml}$. Panel 1: At $A_{1}, 0.5 \mathrm{ml}$ of alcohol administered. The heart stopped for $6 \mathrm{~min}$ (including $3 \mathrm{~min}$ stoppage of drum at $\mathrm{S}$ ). At $\mathrm{N}_{1}, 1 \mathrm{ml}$ of nicotine given. Note the typical action of nicotine characterized by raised baseline (increased tone), acceleration and reduced relaxation with slow gradual recovery. At $\mathrm{A}_{2}, 0.5 \mathrm{ml}$ alcohol and $45 \mathrm{sec}$ later at $\mathrm{N}_{2}, 1 \mathrm{ml}$ of nicotine given. The duration of asystole due to alcohol was cut short and the heart restarted with acceleration and raised baseline showing typical action of nicotine in a mild form. Panel 2: At $\mathrm{N}_{3}, 3 \mathrm{ml}$ nicotine was retested. At $\mathrm{A}_{3}, 0.5 \mathrm{ml}$ of alcohol was given. Prior administration of nicotine prevented the asystolic action of alcohol. At $A_{4}, 0.5 \mathrm{ml}$ alcohol was repeated. Mild acceleration with reduction in amplitude was observed but asystole did not occur, indicating persistence of the action of nicotine $6 \mathrm{~min}$ after its administration. $\mathrm{N}_{4}, 1 \mathrm{ml}$ nicotine tested. The typical action of nicotine was replaced by mild slowing indicating that prior administration of alcohol modified the action of nicotine. Panel 3: At $\mathrm{A}_{5}, 0.5 \mathrm{ml}$ alcohol retested after a long test-free recovery period. Cardiac asystole occurred. Nicotine $0.5 \mathrm{ml}$ was administered after $1.75 \mathrm{~min}$ asystolic period. Heart restarted $1 \mathrm{~min}$ afterwards with slow beats. At $A_{6}$, alcohol and at $N_{6}, 1 \mathrm{ml}$ nicotine tested. Heart restarted $35 \mathrm{sec}$ afterwards. Panel 4: At $\mathrm{A}_{7}, 0.5 \mathrm{ml}$ alcohol and $1.5 \mathrm{ml}$ nicotine given simultaneously. Baseline rose but asystole was prevented, indicating dominance of nicotine action. At $A_{8}$ and $A_{9}$, alcohol was ineffective due to persistence of action of nicotine. Panel 5: $\mathrm{A}_{10}$, alcohol repeated after long rest. Asystole occurred. At Ach, $0.3 \mathrm{ml}$ of acetylcholine $10^{-5} \mathrm{Gm} / \mathrm{ml}$ given. Heart did not restart for $2 \mathrm{~min}$. At $\mathrm{N}_{7}, 1 \mathrm{ml}$ nicotine given. Heart restarted with a raised baseline and eventually recovered. 
The period of asystole was cut short from $6 \mathrm{~min}$ to $1 \mathrm{~min}$. Panel 2 shows that prior administration of a heavy dose of nicotine completely prevented the production of cardiac asystole by 2 successive doses of alcohol given 2 and $5 \mathrm{~min}$ after nicotine. Also the administration of alcohol considerably modified the action of nicotine as there was no acceleration and no rise in baseline when nicotine was tested later soon after the second dose of alcohol. Only slowing of heart rate occurred. Panel 3 shows that after due recovery the heart could be stopped again with same dose of alcohol as before. After an asystolic period of $1.75 \mathrm{~min} 0.5 \mathrm{ml}$ (half the previous dose) of nicotine was administered. The heart restarted with a slow rate but with increased ventricular amplitude $1 \mathrm{~min}$ after the administration of nicotine. In a later trial $1 \mathrm{ml}$ of nicotine was administered $45 \mathrm{sec}$ after cardiac asystole had been produced with alcohol. The heart restarted $35 \mathrm{sec}$ after the administration of nicotine and the duration of cardiac asystole was cut short from $7 \mathrm{~min}$ to $1.25 \mathrm{~min}$. Panel 4 shows action due to simultaneous administration of $0.5 \mathrm{ml}$ of alcohol and $1.5 \mathrm{ml}$ of nicotine. Cardiac asystole was prevented and a miniature effect of nicotine with raised baseline followed by irregular rhythm was seen. Subsequently repetition of alcohol in 2 successive doses did not produce any effect as happened previously in Panel 2. Panel 5: Repetition of alcohol again stopped the heart. Administration of $0.3 \mathrm{ml}$ of $10^{-5} \mathrm{Gm} / \mathrm{ml}$ of acetylcholine $1 \mathrm{~min}$ after asystole did not restart the heart for about $2 \mathrm{~min}$ and nicotine was administered $3 \mathrm{~min}$ after the onset of asystole. The heart restarted in less than $30 \mathrm{sec}$ with typical miniature nicotine effect.

In a total of 56 trials in the frog and rabbit hearts nicotine was successful in restarting the heart in 52 trials (Table I). However it always succeeded in one or the other trial in each heart. Acetylcholine cut short the period of asystole only in 16 out of the 56 trials. The latency of action of acetylcholine was also greater. Thus acetylcholine was less effective than nicotine in restarting the heart but prior or simultaneous administration of either nicotine or acetylcholine antagonized the inhibitory action of alcohol and prevented

Table I. Effectiveness of Nicotine and Acetylcholine on Asystolic Hearts

\begin{tabular}{l|c|cc|cc|cc}
\hline & $\begin{array}{c}\text { Total No. of } \\
\text { asystolic trials }\end{array}$ & \multicolumn{2}{|c|}{ No. of trial } & $\begin{array}{c}\text { No. of trials in } \\
\text { which nicotine } \\
\text { was effective }\end{array}$ & $\begin{array}{c}\text { No. of trials in } \\
\text { which actylcholine } \\
\text { was effective }\end{array}$ \\
\cline { 3 - 7 } & & F & R & F & R & F & R \\
\hline Alcohol & 56 & 38 & 18 & 36 & 16 & 14 & 2 \\
Cortisone & 35 & 27 & 8 & 25 & 8 & 20 & 6 \\
Hydrocortisone & 48 & 39 & 9 & 38 & 7 & 20 & 2 \\
Prednisolone & 28 & 20 & 8 & 25 & 6 & 5 & 3 \\
F : frog hearts; & $\mathbf{R}:$ rabbit hearts & & & & &
\end{tabular}


the onset of asystole or shortened its duration. The interaction between nicotine and alcohol was more intimate as prior administration of alcohol modified the action of nicotine.

\section{Prednisolone:}

In a dose of 0.1 to $0.3 \mathrm{ml}$ of $0.5 \%$ solution, prednisolone stopped the heart in diastole; control experiments with same volume of $0.5 \%$ alcohol were ineffective in producing significant inhibitory effect. Hence the presence of small quantity of alcohol used as solvent for preparing the test solution of prednisolone did not contribute to the production of cardiac asystole by prednisolone. Both nicotine (0.5 to $3 \mathrm{ml}$ of $10^{-4} \mathrm{Gm} / \mathrm{ml}$ ) and acetylcholine ( 1 to $3 \mathrm{ml}$ of $10^{-7}$ to $10^{-4} \mathrm{Gm} / \mathrm{ml}$ ) were effective in restarting the heart stopped by prednisolone. Fig. 2 shows the record of a frog and a rabbit heart. Panel 1 shows that in a frog heart control with $0.5 \mathrm{ml}$ of $0.5 \%$ alcohol was practically ineffective but the same dose of prednisolone promptly stopped the heart. Administration of $3 \mathrm{ml}$ of acetylcholine $10^{-4} \mathrm{Gm} / \mathrm{ml}, 70 \mathrm{sec}$ after asystole, restarted the heart within 30 sec. Panels 2 and 3 show the record of a rabbit heart. Panel 2 shows stoppage of heart with $0.1 \mathrm{ml}$ of $0.5 \%$ prednisolone. The total duration of asystole was $55 \mathrm{sec}$. Later the same dose of prednisolone was repeated and $22 \mathrm{sec}$ afterwards $0.1 \mathrm{ml}$ of acetylcholine $10^{-7} \mathrm{Gm} / \mathrm{ml}$ was administered. The heart restarted $18 \mathrm{sec}$ after the administration of acetylcholine. The duration of asystole was cut short from $55 \mathrm{sec}$ to $40 \mathrm{sec}$. Panel 3 shows control test with $0.1 \mathrm{ml}$ of $0.5 \%$ alcohol. Because of greater sensitivity of rabbit hearts to alcohol, some inhibitory action was recorded. Subsequently $0.1 \mathrm{ml}$ of $0.5 \%$ prednisolone and $0.1 \mathrm{ml}$ of $10^{-7} \mathrm{Gm} / \mathrm{ml}$ of acetylcholine were administered simultaneously. The duration of asystole was cut down to $40 \mathrm{sec}$. Finally the action of prednisolone alone was tested. The heart stopped for $55 \mathrm{sec}$ as in the beginning of the test indicating no change in the responsiveness of the heart to prednisolone with the passage of time.

The duration of asystole was more brief in rabbit hearts than in frog hearts because of dilution of dose. Asystole was shorter with prednisolone than with cortisone. Both acetylcholine and nicotine were effective in antagonizing the action of prednisolone if given just before or with prednisolone. The frog heart required a much larger dose of acetylcholine than the rabbit heart for revival.

\section{Cortisone :}

In doses of 0.1 to $0.5 \mathrm{ml}$ of 0.5 to $1 \%$ solution cortisone stopped the frog and rabbit hearts. Control test with equivalent dose of alcohol did not produce significant inhibitory action. The duration of asystole with cortisone was greater than with prednisolone. Nicotine was more effective than acetylcholine in restarting hearts stopped with cortisone. Prior administration of 

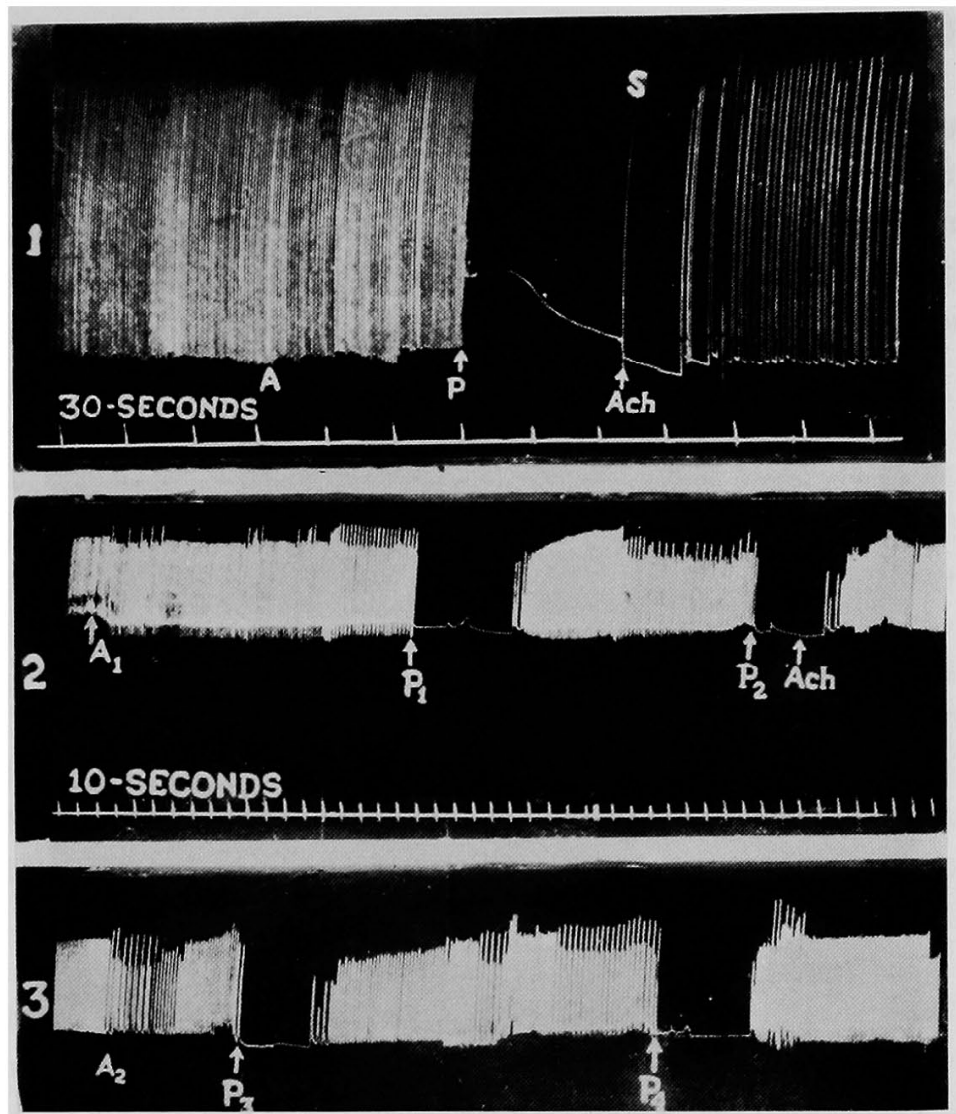

Fig. 2. Panel 1: Frog heart. At A, $0.5 \mathrm{ml}$ of $0.5 \%$ alcohol was tested. At $\mathrm{P}, 0.5 \mathrm{ml}$ of $0.5 \%$ prednisolone was administered. The heart stopped and did not revive for $70 \mathrm{sec}$ when the drum was stopped (S) and $3 \mathrm{ml}$ acetylcholine (Ach) $10^{-4} \mathrm{Gm} / \mathrm{ml}$ was given. The heart restarted within $30 \mathrm{sec}$. In earlier 2 tests with the same dose of prednisolone (not shown here) cardiac asystole lasted for $4 \mathrm{~min}$. Thus acetylcholine cut short the duration of asystole considerably. Panels 2 and 3: Rabbit heart. At $\mathrm{A}_{1}$, control with $0.1 \mathrm{ml}$ of $0.5 \%$ alcohol was conducted and at $P_{1}, 0.1 \mathrm{ml}$ of $0.5 \%$ prednisolone was tested. The heart stopped for $55 \mathrm{sec}$. The shorter duration of asystole in rabbit hearts was due to greater dilution of the already small dose in the perfusion fluid. At $P_{2}, 0.1 \mathrm{ml}$ of prednisolone repeated. At Ach, $0.1 \mathrm{ml}$ of $10^{-7} \mathrm{Gm} / \mathrm{ml}$ acetylcholine was given $22 \mathrm{sec}$ after cardiac asystole; the heart restarted $18 \mathrm{sec}$ afterwards. At $\mathrm{A}_{2}$, control with $0.1 \mathrm{ml}$ of $0.5 \%$ alcohol was conducted. Some inhibitory action of alcohol was present. At $\mathbf{P}_{3}, 0.1 \mathrm{ml}$ of prednisolone and $0.1 \mathrm{ml}$ of acetylcholine $10^{-7} \mathrm{Gm} / \mathrm{ml}$ were given simultaneously. The duration of asystole was cut down to $40 \mathrm{sec}$. At $\mathbf{P}_{4}$, prednisolone was retested. The heart stopped for $55 \mathrm{sec}$ as in the beginning of the test.

nicotine antagonized action of cortisone and prevented asystole or cut short its duration. Simultaneous administration of nicotine or acetylcholine in suitable doses with cortisone also prevented cardiac arrest or shortened its dura- 
tion. Fig. 3 shows the record of frog heart. Panel 1 shows alcohol control followed by cardiac arrest with $0.5 \mathrm{ml}$ of $1 \%$ cortisone. The total duration of ventricular asystole was $3.75 \mathrm{~min}$ with occasional auricular activity. Panel 2 shows control with same strength of alcohol with minimum inhibitory action. Later, simultaneous administration of $0.5 \mathrm{ml}$ of $1 \%$ cortisone and $3 \mathrm{ml}$ of $10^{-4} \mathrm{Gm} / \mathrm{ml}$ of nicotine prevented cardiac asystole. There was typical rise in baseline due to nicotine with reduction of ventricular contraction. Panel 3

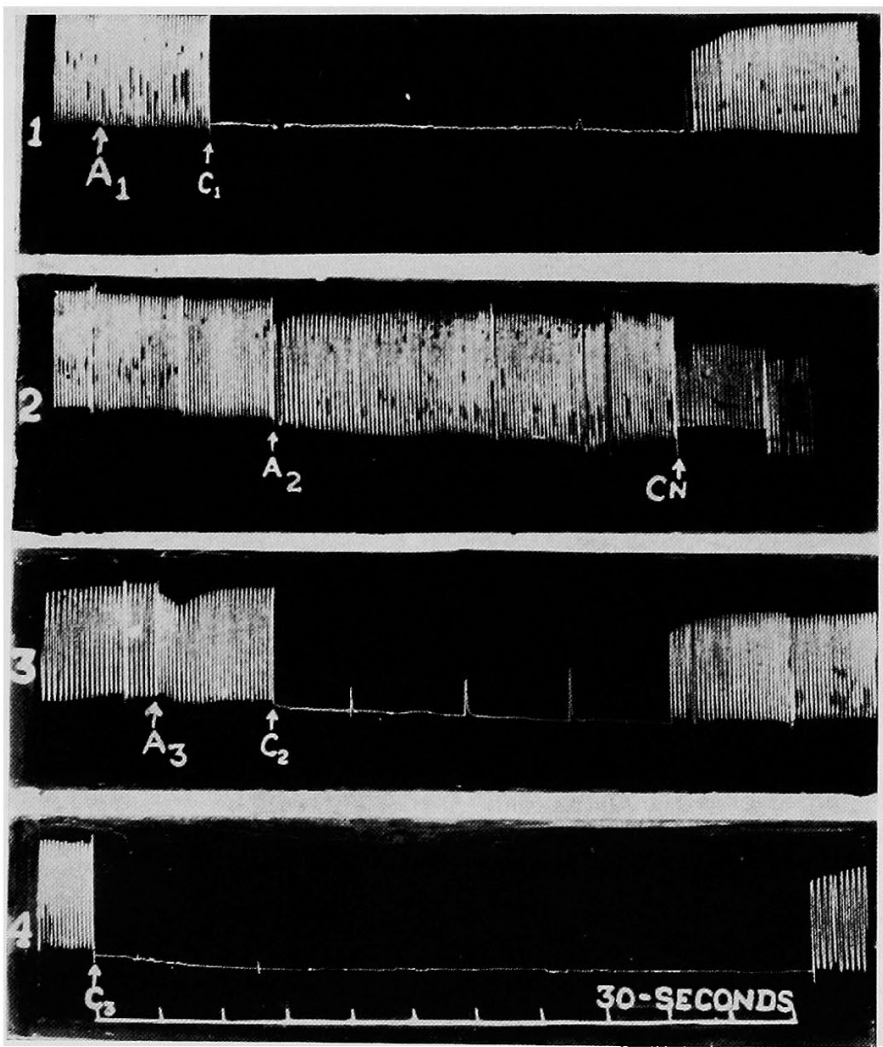

Fig. 3. Frog heart. Panel 1: At $\mathrm{A}_{1}$, control with $0.5 \mathrm{ml}$ of $1 \%$ alcohol was conducted. At $\mathrm{C}_{1}, 0.5 \mathrm{ml}$ of $1 \%$ cortisone was tested. Cardiac asystole occurred for $3.75 \mathrm{~min}$. Evidence of atrioventricular block was seen during recovery. The block cleared abruptly. Panel 2: At $\mathrm{A}_{2}, 0.5 \mathrm{ml}$ of $1 \%$ alcohol was tested. Mild inhibitory effect occurred. At $\mathrm{CN}, 0.5 \mathrm{ml}$ of $1 \%$ cortisone and $3 \mathrm{ml}$ of $10^{-4} \mathrm{Gm} / \mathrm{ml}$ nicotine were given simultaneously. The cardiac asystole was prevented. Typical baseline rise (due to nicotine) with reduction in ventricular contraction occurred. Panel 3: At $\mathrm{A}_{3}$, control with $0.5 \mathrm{ml}$ of $1 \%$ of alcohol was repeated. At $\mathrm{C}_{2}, 0.5 \mathrm{ml}$ of $1 \%$ cortisone and $0.5 \mathrm{ml}$ of acetylcholine $10^{-5} \mathrm{Gm} / \mathrm{ml}$ were given together. Cardiac asystole was not prevented but the duration was considerably reduced as the heart restarted in $35 \mathrm{sec}$ with slow rate which changed to normal abruptly due to clearance of atrioventricular block. Panel 4: At $\mathrm{C}_{3}, 0.5 \mathrm{ml}$ of $1 \%$ cortisone was tested. Cardiac asystole occurred for $5.75 \mathrm{~min}$. 
shows that simultaneous administration of $0.5 \mathrm{ml}$ of $1 \%$ cortisone and $0.5 \mathrm{ml}$ of $10^{-5} \mathrm{Gm} / \mathrm{ml}$ of acetylcholine did not prevent asystole but the heart restarted $35 \mathrm{sec}$ afterwards and the duration of asystole was reduced considerably. Recovery was complete in $3 \mathrm{~min}$ as the artioventricular block cleared. Panel 4 shows that on repetition of same dose of cortisone cardiac asystole lasted for $5.75 \mathrm{~min}$, indicating that responsiveness of the heart to asystolic action of cortisone has not decreased during the experiment.

\section{Hydrocortisone :}

Hydrocortisone in a dose of 0.2 to $0.5 \mathrm{ml}$ of $0.5 \%$ solution produced cardiac asystole both in frog and rabbit hearts. Like cortisone, nicotine was more effective than acetylcholine in restarting hearts stopped with hydrocortisone. If nicotine was administered simultaneously with hydrocortisone cardiac arrest was prevented or its duration shortened. Control experiments with corresponding strengths of alcohol did not produce any significant cardiac inhibition. Fig. 4 shows extracts of record of 2 hearts. Panel 1 shows cardiac arrest with $0.5 \mathrm{ml}$ of $0.5 \%$ and $0.5 \mathrm{ml}$ of $1 \%$ hydrocortisone for $40 \mathrm{sec}$ and $7.5 \mathrm{~min}$ respectively. Panel 2 shows control test with $0.5 \mathrm{ml}$ of $1 \%$ alcohol. Later $0.5 \mathrm{ml}$ of $1 \%$ hydrocortisone and $1 \mathrm{ml}$ of $10^{-6} \mathrm{Gm} / \mathrm{ml}$ acetylcholine were given simultaneously. The duration of cardiac asystole was cut short from $7.5 \mathrm{~min}$ to 1 1 min after which the heart restarted with very slow rate. The heart returned to full activity in about $3.25 \mathrm{~min}$ after asystole. Panel 3 shows reduction in duration of asystole from $7.5 \mathrm{~min}$ to $3.5 \mathrm{~min}$ when hydrocortisone $0.5 \mathrm{ml}$ of $1 \%$ and $1 \mathrm{ml}$ of $10^{-5} \mathrm{Gm} / \mathrm{ml}$ acetylcholine were given together. Later test with $0.5 \mathrm{ml}$ of $0.5 \%$ hydrocortisone showed that the responsiveness of the heart to hydrocortisone was the same as in the beginning of the experiment. Panel 4 is the record of another frog heart showing brief cardiac asystole and prompt recovery within $30 \mathrm{sec}$ after the administration of $0.5 \mathrm{ml}$ of $0.5 \%$ hydrocortisone. Later test with simultaneous dose of $0.5 \mathrm{ml}$ of $0.5 \%$ hydrocortisone and $3 \mathrm{ml}$ of acetylcholine $10^{-4} \mathrm{Gm} / \mathrm{ml}$ showed that cardiac arrest was almost prevented although inhibitory effects were present.

The above results indicate that cardiac asystolic action of inhibitory doses of alcohol and glucocorticoids is antagonized both by nicotine and by acetylcholine in appropriate doses. Nicotine, however, is more effective in reviving the heart after asystole has occurred. Table I shows the number of trials in which nicotine and acetylcholine were effective in antagonizing the inhibitory action of alcohol and glucocorticoids. The duration of asystole with the same dose varied from heart to heart but increased with dose in the same heart. On an average $0.5 \mathrm{ml}$ of $50 \%$ alcohol produced asystole for 3 to $8 \mathrm{~min}$ while $0.5 \mathrm{ml}$ of $0.5 \%$ corticoid stopped the hearts for 1 to $3 \mathrm{~min}$. Thus the asystolic action of glucocorticoids was stronger than that of alcohol. Because of possibility of 

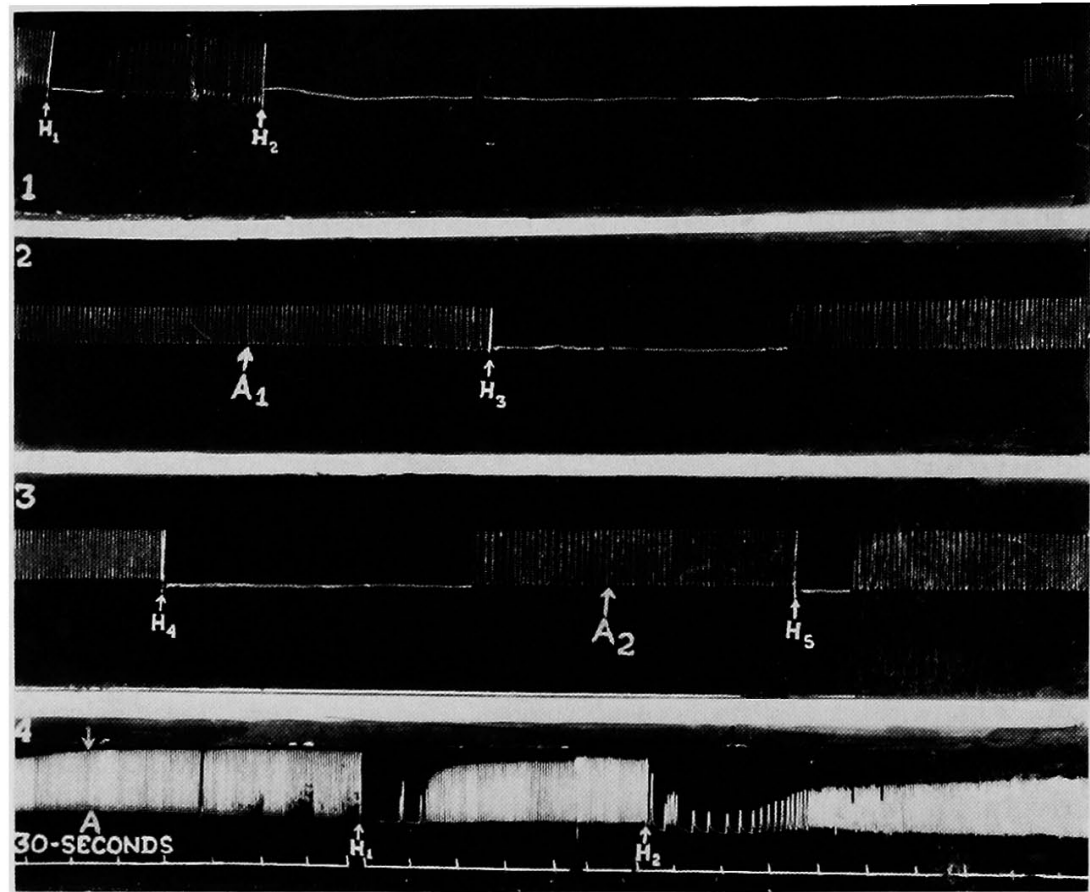

Fig. 4. Panels 1,2, and 3: Frog heart. Panel 1: At $\mathrm{H}_{1}$, hydrocortisone $0.5 \mathrm{ml}$ of $0.5 \%$ was tested. Transient cardiac asystole for 40 sec occurred with prompt recovery. At $\mathrm{H}_{2}, 0.5 \mathrm{ml}$ of $1 \%$ hydrocortisone was given. Cardiac asystole lasted $7.5 \mathrm{~min}$. Panel 2: $\mathrm{A}_{1}$, control with $0.5 \mathrm{ml}$ of $1 \%$ alcohol, had no effect. At $\mathrm{H}_{3}, 0.5 \mathrm{ml}$ of $1 \%$ hydrocortisone and $1 \mathrm{ml}$ of $10^{-6} \mathrm{Gm} / \mathrm{ml}$ acetylcholine were given. Cardiac asystole was not prevented but the duration of asystole was cut short to $1 \mathrm{~min}$ and full recovery occurred in $3.25 \mathrm{~min}$. Panel 3: At $\mathrm{H}_{4}, 0.5 \mathrm{ml}$ of $1 \%$ hydrocortisone and $1 \mathrm{ml}$ of $10^{-5} \mathrm{Gm} / \mathrm{ml}$ acetylcholine were given together. Cardiac asystole was not prevented but it was cut short to $3.5 \mathrm{~min}$. At $\mathrm{A}_{2}$, alcohol control. At $\mathrm{H}_{5}$, $0.5 \mathrm{ml}$ of $0.5 \%$ hydrocortisone was tested. The asystolic period was about the same as in the beginning of the experiments. Panel 4: Another frog heart. At $\mathrm{A}, 0.5 \mathrm{ml}$ of $0.5 \%$ alcohol was tested. At $\mathrm{H}_{1}, 0.5 \mathrm{ml}$ of $0.5 \%$ hydrocortisone was given. Brief asystole with prompt recovery occurred. At $\mathrm{H}_{2}, 0.5 \mathrm{ml}$ of $0.5 \%$ hydrocortisone was given with $3 \mathrm{ml}$ of $10^{-4} \mathrm{Gm} / \mathrm{ml}$ of acetylcholine. Asystole was almost prevented although inhibitory effects were present.

release of catecholamines by nicotine and acetylcholine from local neural elements in the heart, the action of adrenaline and noradrenaline in a concentration of $10^{-6} \mathrm{Gm} / \mathrm{ml}$ was tested on hearts stopped with alcohol and glucocorticoid. Catecholamines were not very effective in restarting the stopped hearts.

\section{Discussion}

The investigations with appropriate controls unequivocally demonstrate that alcohol and glucocorticoids in inhibitory doses produced cardiac asystole 
and that prior or simultaneous administration of nicotine or acetylcholine antagonized the inhibitory action of alcohol and glucocorticoids. Nicotine was more effective than acetylcholine in preventing the asystolic action, in reducing the duration of asystole and in restarting the stopped hearts. Occasional failure of nicotine (Table I) could be due to its own inhibitory action. Nicotine and acetylcholine have been shown to have biphasic action on the heart, stimulating in low concentrations and depressing in high concentrations. ${ }^{4), 6)^{2}}$ The stimulating concentrations of nicotine and acetylcholine were used effectively in the present investigations for counteracting the inhibitory action of alcohol and corticoids. Acetylcholine has been shown to restart the spontaneously stopped hearts ${ }^{4,7)}$ and also hearts stopped with quinidine ${ }^{7}$. The mechanism of excitatory action of acetylcholine has been investigated and acetylcholine has been found to release catecholamines from local neural elements present in the heart. ${ }^{8}$ ) Nicotine is a ganglionic depolariser and could also release catecholamines from local nerve cells present in the heart. The present investigations show that catecholamines were not very effective in restarting the hearts stopped with alcohol and glucocorticoids. Hence some other explanation must be sought. The mechanism of cardiac asystole produced by alcohol and glucocorticoids is not clear. Like nicotine and acetylcholine, biphasic effect of alcohol ${ }^{1,2}$ ) and glucocorticoids ${ }^{3}$ ) have also been reported. In the present work a competitive action has been found between the stimulating concentrations of nicotine and acetylcholine and inhibitory concentrations of alcohol and glucocorticoids. It appears that the excitatory and inhibitory processes in the heart are coupled to some common receptor or enzyme system through which the same substance could produce opposite effects depending upon concentration.

\section{REFERENGES}

1. Pathak CL: Indian J Med Sci (in press)

2. Pathak CL: Indian J Physiol Pharmacol (in press)

3. Pathak CL: Jap J Pharmacol (in press)

4. Pathak CL: Am J Physiol 195: 61, 1958

5. Pathak CL: Experientia 28: 650, 1972

6. Pathak CL: Indian J Med Res 46: 442, 1958

7. Burn JH: Lectures on the Scientific Basis of Medicine, Athlone Press, University of London, London, Vol III, 127, 1953-54

8. Hoffmann F, Hoffmann EJ, Middleton S, Talesnik J: Am J Physiol 144: 189, 1954 